\title{
The Hydrogen Grand Challenge
}

\author{
Andreas Borgschulte* \\ Laboratory 502 Advanced Analytical Technologies, EMPA - Swiss Federal Laboratories for Materials Science \& Technology, \\ Dübendorf, Switzerland
}

Keywords: hydrogen production, hydrogen storage, surface science, materials science, solar water splitting, electrolysis, hydrogen selective membrane, fuel cell

\section{INTRODUCTION}

More than $90 \%$ of the world's growing energy demand is satisfied by fossil fuels (BP Statistical Review ..., 2015) ${ }^{1}$. One consequence of the unrestrained use of this technology is the continuous increase of the $\mathrm{CO}_{2}$ level of the atmosphere ${ }^{2}$. There are also the challenges associated with the limitations of the corresponding resources (Hubbert, 1956; BP Statistical Review ..., 2015). Climate change as a consequence of the growing $\mathrm{CO}_{2}$ level (see text footnote 2, ESRL Global Monitoring Division, 2015) has been identified as one of the most critical challenges facing mankind and requires immediate action: "The Paris Agreement aims to strengthen the global response to the threat of climate change, (... ) by low greenhouse gas emissions development, in a manner that does not threaten food production" (United Nations Framework ..., 2015). How to reach the corresponding significant reduction of $\mathrm{CO}_{2}$ emission by 2050 is not defined in this document, but it implies that mankind must transform its energy technology from a fossil to a renewable basis. Numerous studies and publications have indicated that the sun's energy and its derivatives (wind, water) are by far sufficient to supply world's energy demand (see, e.g., Smalley, 2005; Züttel et al., 2010); but the large daily and seasonal power variation of renewable energy is an additional complication for a wide spread replacement of fossil energy by renewable energy. This difficulty is drastically demonstrated by the economic crisis of some electricity companies (How to loose half ..., 2013), which cannot cope with the growing but strongly varying supply of renewable energy while maintaining the public mandate of a safe and continuous electricity supply. Large scale daily and seasonal energy storage is thus urgently needed to make the transformation toward a renewable energy society possible. Various technologies are under discussion including mechanical storage (fly wheel, pumped hydroelectricity, compressed gas storage, etc.), and electrochemical storage (batteries). Here, we do not want to diminish the potential of these storage possibilities but highlight the one of energy storage by the production of chemical fuels such as hydrogen (Schlapbach, 2009). One argument is the sheer size: seasonal energy storage for northern countries means the storage of roughly $50 \%$ of their total annual demand: with an approximated consumption of $10 \mathrm{~kW}$ per capita, this corresponds to $158,000 \mathrm{MJ}$ to be stored in $87,600 \mathrm{~kg}$ Li-batteries, or by $3285 \mathrm{~kg}$ fuel oil (diesel) per person and year. Apart from technical challenges, these numbers illustrate another important issue: many house holders in Europe are indeed used to store several $1000 \mathrm{l}$ of fuel oil for heating. Changing the energy carrier hydrocarbons implies that the corresponding infrastructure supplying more than $50 \%$ of the world's energy has to be replaced (pipelines for oil and gas, fuel stations, end user installations, the automotive and aviation industry, market models, etc.). Alternatively, the existing infrastructure could be used in accordance with the ambitious Paris agreement (United Nations Framework ..., 2015), if the hydrocarbons are produced from renewable energy. This is the great challenge (Smalley, 2005), which may be partly overcome by tackling the Hydrogen Grand Challenge as described in the following.

Accepted: 18 March 2016

Published: 12 April 2016

Citation:

Borgschulte A (2016) The Hydrogen

Grand Challenge.

Front. Energy Res. 4:11.

doi: 10.3389/fenrg.2016.00011

\footnotetext{
${ }^{1}$ Total primary energy production in 2014: $12^{\prime} 924 \mathrm{MOE}$ (million tons of oil equivalent) $=5.4 \times 10^{23} \mathrm{~J}$; oil, natural gas, and coal: 11'158 MOE; Nuclear energy: 574 MOE; Hydroelectricity 879 MOE; Renewable Energies: 316.9 MOE; from BP Statistical Review ... (2015), p. 41.

${ }^{2} \mathrm{http}: / /$ www.ipcc.ch/
} 


\section{THE CHALLENGES}

Light is the primary energy of the sun, and its conversion to chemical fuel has taken place on a Giga Joule scale by photosynthesis for millions of years. This imposing proof of concept of renewable energy storage may be taken as a guide to a renewable energy technology ["artificial photosynthesis" (Nocera, 2012)], although agriculture as a direct utilization of photosynthesis is not recommended (see statement of the Paris agreement quoted above). To store energy, plants split water releasing molecular oxygen, protons, and electrons at a high (negative) electrochemical potential, at which some algae can produced molecular hydrogen (Rupprecht et al., 2006). Under normal conditions, plants do not produce hydrogen, but "organic hydrides,"3 which are used to eventually produce carbon based chemical energy carriers by reduction of $\mathrm{CO}_{2}$. Nature has thus solved energy storage problem by splitting water, which may be translated to technical needs as follows (Züttel et al., 2008):

- Production of hydrogen: harvesting of solar light, conversion of photon energy into an electro-chemical potential, electro-catalytic conversion of water into oxygen, protons and electrons.

${ }^{3}$ In photosynthesis, the energy of the excited photosystem is transferred via proton coupled electron transfer reactions, such as quinone $+2 \mathrm{H}^{+}+2 \mathrm{e}^{-} \rightarrow$ hydroquinone (Voet and Voet, 2011). These compounds may be seen as the biochemistry analog to inorganic metal hydrides in a Ni-MH battery, i.e., as organic hydrides. The analog is so good, that one can use it as a battery concept (Huskinson et al., 2014).
- Hydrogen storage: directly as molecular hydrogen, and by chemical reaction with matter, in metal hydrides, by $\mathrm{CO}_{2}$, carbon-carbon chain-linking, and reduction to hydrocarbons. - Hydrogen end use: fuel cells and combustion.

These items needs define the technical part of the hydrogen grand challenge. As the supply of energy to people is a fundamental necessity to people, the hydrogen grand challenge has also ecological, economic, and social boundaries.

The hydrogen grand challenge may be divided into the three topical areas hydrogen production, storage, and end use, which are linked via the closed hydrogen cycle, by related scientific fundamentals, and through cross-cutting safety issues, and socioeconomic boundary conditions (see Figure 1). The targets of these topical areas are well defined: high conversion efficiencies of hydrogen production (Carmo et al., 2013; Ebbesen et al., 2014) and hydrogen use (Kirubakaran et al., 2009; Fernández et al., 2016), and a high storage density of hydrogen storage (Graves et al., 2011; Lai et al., 2015), all at economically reasonable price (McFarland, 2014). However, specific challenges cannot be drawn from these topics, as the performance of the hydrogen cycle is based on the consecutive functioning of all steps as a whole. As an example, if hydrogen storage is realized by reaction of hydrogen with $\mathrm{CO}_{2}$ producing hydrocarbons, low temperature fuel cells cannot be used. In this case, preferable end use of the fuel may be in internal and external combustion engines, high temperature fuel cells and heating, which usually have lower efficiencies than pure hydrogen conversion devices. Thus, although the challenge hydrogen storage is technically solved, the overall system performance

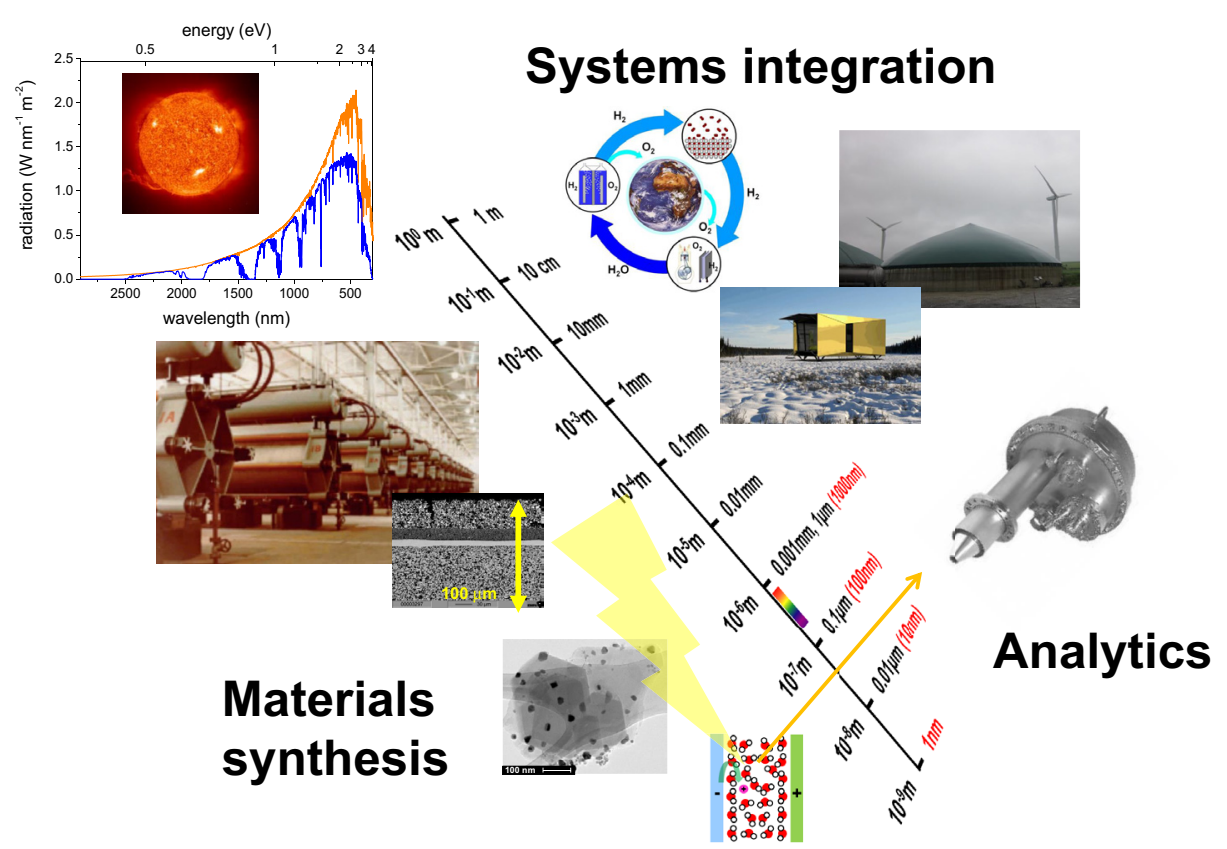

FIGURE 1 | The three hydrogen grand challenges in a nutshell: although at the beginning, the (atomistic) phenomena as characterized by state-ofthe art analytics (challenge 1) are utilized by advance materials (challenge 2), which are part of big systems (challenge 3 ) to store and distribute the energy of the sun. The hydrogen grand challenge comprises research and development from the nano-scale to the macroscopic world. Pictures are from NASA, and references (Züttel et al., 2008; Bielmann et al., 2011; Vogt et al., 2014). 
is less than the one of the pure hydrogen system with hydrogen storage in pressurized cylinders (having other critical issues). The performance of the system is thus equally defined by the atomistic phenomena in the materials as well as at the system level. We consider the corresponding scientific bottlenecks as the specific challenges of the Hydrogen Grand Challenge (see also Figure 1):

- Challenge 1: time-resolved surface science analytics under harsh conditions,

- Challenge 2: materials science for hydrogen devices,

- Challenge 3: systems integration.

The overall hydrogen grand challenge is a true challenge of mankind (Nocera, 2012). Frontiers in hydrogen would like to stimulate research on scientific bottlenecks, in which breakthroughs will have significant impact on the hydrogen grand challenge as a whole.

Harvesting of solar light and the conversion of the energy into an electrochemical potential is a prerequisite of hydrogen production. However, these tasks define the topic "photovoltaics," and are as such too big to be implemented in this journal. The starting point of hydrogen production is thus electricity as produced by renewable energy, which may also include other sources than light (i.e., wind and hydroelectricity). As exceptions, Frontiers in Energy Research section Hydrogen Storage and Production would like to include photoelectrochemical and photocatalytic hydrogen production.

Hydrogen production may be seen as the starting point in a closed circle using hydrogen as a renewable energy carrier. The fundamental processes of renewable hydrogen production by electrolysis are relatively well understood and pilot plants have demonstrated the feasibility on the industrial scale. Nevertheless, today's hydrogen stems to $95 \%$ from fossil sources. Research and development of hydrogen production is needed to make renewable hydrogen cost competitive to fossil hydrogen. This generates demands for fundamental research on new concepts and materials in electrolysis. The corresponding scientific bottlenecks are relatively easy assigned, though not similarly easy overcome.

Electrolysis is an electro-chemical process taking place at two spatially separated electrodes. The Faraday efficiency for water electrolysis is near one; this can be different in more complex reactions such as the electro-chemical $\mathrm{CO}_{2}$ reduction (Kuhl et al., 2012). The voltage-current relation is thus sufficient to characterize the reaction and defines the overall efficiency (see Figure 2). Although additional losses may add up, the electron transfer reactions at the electrode-electrolyte interfaces are the rate-limiting step. Here, the main losses occur, and materials improvements will have highest impact, also because to minimize amount of the often precious materials [e.g., platinum, iridium for PEM electrolysers (Reier et al., 2015)]. This grand challenge of finding Advanced Materials for electro-catalysis may be simplified, if a sound scientific description of the process is available.

Theories for electron-transfer at electrode-electrolyte interfaces are still based on semi-empirical ideas, be it the Butler-Volmer theory (Erdey-Grúz and Volmer, 1930; Nørskov et al., 2004) or the Marcus theory (Marcus, 1993; Gao et al., 2000; Feldberg, 2010). Due to the polarity of the solvent water, the interface ("electrochemical double layer," EDL) depends on

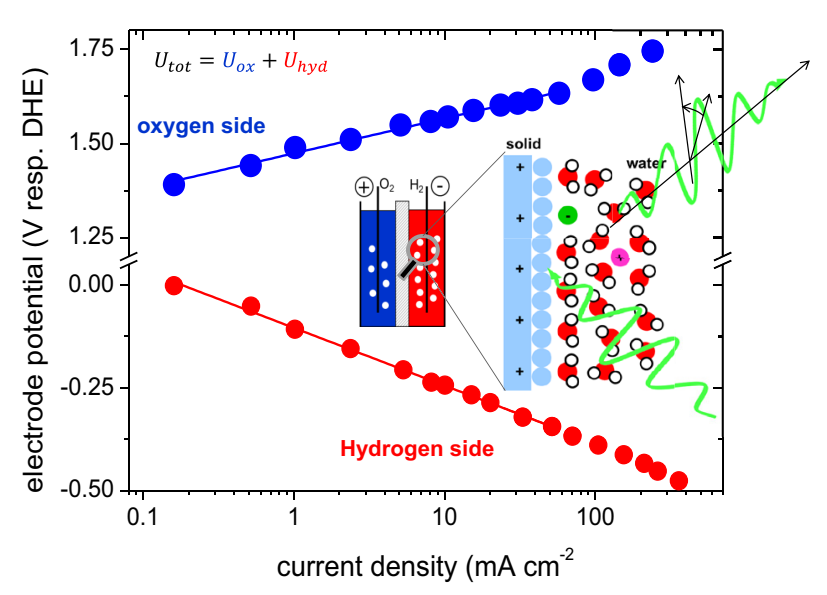

FIGURE 2 | Large panel: electrode potentials during alkaline water electrolysis. The required voltage to split water at a given current density is the sum of both potentials, and defines the efficiency of the electrolysis process. The potentials result from the electrochemical (half-) reactions at the electrodeelectrolyte interface as sketched in the inset. An analysis of the dynamic process at this interface is an analytical challenge. Novel optical spectroscopy (green lines) may give further insights. Data from Miles et al. (1976).

the surface of the electrode, the dynamic properties of the water, impurities, and external parameters such as temperature. The classical description of corresponding electric field is obtained by solving the Poisson equation. However, the resulting potential barrier is of dynamic origin, i.e., the atomistic mechanism how such a barrier is overcome remains elusive. For example, an ion hopping from the neutral metal surface over this barrier into the electrolyte changes the local polarization drastically. The influence of the dynamic behavior is of highest importance for hydrogen production by homogenous solar water splitting due to the transient nature of the process. The grand challenge is to characterize such an interface - surface science under harshest conditions.

\section{Challenge 1: Time-Resolved Surface Science Analytics under Harsh Conditions}

Surface science has a long tradition in hydrogen based technologies: catalytic processes involving hydrogen such as Haber-Bosch synthesis (Ertl, 1990), steam reforming, methanation (Borgschulte et al., 2013, 2016), hydrogen combustion (Fernández et al., 2016), etc. The surface is the gateway of hydrogen entering (and leaving) bulk material (Schlapbach, 1992), which is relevant in hydrogen storage in metal hydrides (Borgschulte et al., 2008) and in hydrogen selective membranes (Delmelle et al., 2016) in addition to the electro-catalytic hydrogen production as discussed above. A multitude of experimental tools [photoemission (Salmeron and Schlögl, 2008; Delmelle et al., 2015); Infrared spectroscopy (Wandlowski et al., 2004; Yang et al., 2006); mass spectrometry (Johansson et al., 2008); STM (Mitsui et al., 2003; Wandlowski et al., 2004; Schlaup et al., 2015); tip-enhanced Raman spectroscopy (Pettinger et al., 2004); EXAFS (Ferri et al., 2011)] were developed in the past aiming at bridging the materials and pressure gap in surface science (Imbihl et al., 2007). Still, the operando characterization of the (electro-) catalytic active 
surface sites remains challenging. The investigation of real-time motions of (electro-) chemical reactions on the atomic level have recently become possible for model systems $\left[\mathrm{H}_{2}\right.$-desorption from $\mathrm{Ru}$ (Frischkorn, 2008), water dynamics (Tielrooij et al., 2010), electron-transfer reactions (Hsu et al., 2014), and solar water splitting (Zhang et al., 2014; Rodenberg et al., 2015)]. The implementation of femto-second time resolution with nanometer spatial resolution is the ultimate goal, and will open new perspectives for functional nanomaterials. Frontiers in Energy Research section Hydrogen Storage and Production would like to stimulate such investigations and their modeling with a focus on the applicability for hydrogen technologies.

\section{Challenge 2: Materials Science for Hydrogen Devices}

Solving the analytic challenge as described above is prerequisite to improve the performance of materials for hydrogen production, storage, and end use. With the rate-limiting steps taking place at the nm-scale (e.g., the EDL), materials functionalization is most efficient at the nanometer scale, too. For a long time, heterogeneous catalysis has been a play-ground for nanoscience (Bell, 2003); maximizing the surface to volume ratio is one of the most common strategies in applied catalysis, which asks for novel nanostructuring technologies (nanoparticle synthesis, surface functionalization, etc., see Figure 3). These ideas can be adopted one-to-one to all hydrogen-related applications, in which the gas-solid interaction at the surface plays an important role, i.e., catalytic $\mathrm{CO}_{2}$ reduction (Borgschulte et al., 2015), catalytic hydrogen combustion (Fernández et al., 2016), catalysts for hydrogen sorption in metal hydrides (Schlapbach, 1992), and electro-catalysis at electrodes for hydrogen production (Carmo et al., 2013), only to mention a few. A particular challenge at electrode processes is the so-called triple-phase boundary. Different to purely catalytic processes, an electro-catalyst facilitates the interaction of electrons, ions, and neutral species. The complex nanostructure of the corresponding electrodes is specific to the type of device: Pt/carbon/Nafion PEM fuel cells (O'Hayre and Prinz, 2004) share only the general idea with Ni/YSZ solid electrolyte SOFC (Wilson et al., 2006), but the materials problems are different. Materials science is needed in both cases to improve properties and to prolong life times. In addition, hydrogen production and reaction with $\mathrm{CO}_{2}$ may take place simultaneously in the same device (Kuhl et al., 2012), the so-called coelectrolysis of water and $\mathrm{CO}_{2}$. Ultimately, harvesting of solar light and $\mathrm{CO}_{2}$ from the atmosphere may be combined with the coelectrolysis of water and $\mathrm{CO}_{2}$ representing the artificial leaf (Nocera, 2012). This approach may gather synergetic advantages, but it also combines all materials science challenges in one single device.

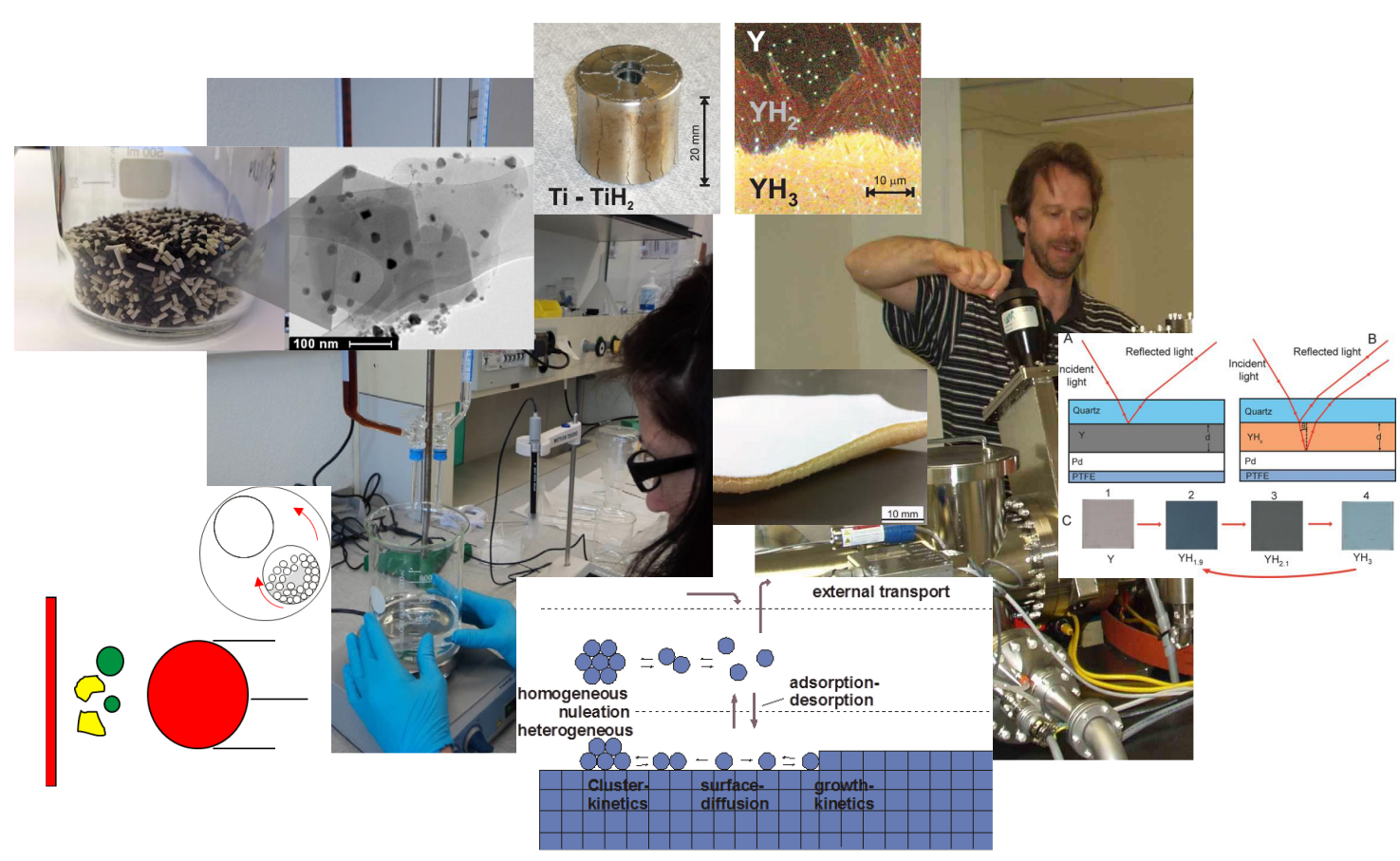

FIGURE 3 | Materials science is only limited by the creativity of the researchers: materials for hydrogen economy may be prepared by mass production methods such a wet chemistry and ball-milling (left side) as well as sophisticated thin film methodologies (right side). Many catalysts (here Ni-particles in a zeolite matrix, left top picture) are prepared by wet chemistry, while ball-milling (left bottom sketch) is a common method for hydrogen storage materials. Thin film preparation such as sputtering (right background picture) is perfectly suited for 2D-devices such as sensors (right picture) and facilitates the investigation of the growth mechanisms and atomistic phenomena (middle bottom sketch), which define the resulting materials properties both for wet chemistry as well as physical deposition. Thin films can stabilize systems suffering from hydrogen-induced mechanical stress (top middle figures: mechanical deformation of bulk Ti after hydrogenation, similar stress is induced in yttrium hydride films, but they are kept stable due to adhesion to the substrate). Membranes (middle photo) and electrodes are commonly prepared by wet chemistry methods as well as thin film deposition techniques. 
Hydrogen is the lightest of all elements, and thus the diffusion of hydrogen is exceptionally fast in many materials. This enables peculiar phenomena, in which hydrogen is readily exchanged in the bulk of materials, which may be exploited by applications in hydrogen storage (Züttel et al., 2008) and hydrogen selective membranes. However, hydrogen diffusion is not fast in all solid systems; complex hydrides as potential hydrogen storage materials suffer from slow sorption kinetics. To improve kinetics, one tries to shorten the diffusion paths. The latter requires diffusion path lengths on the order of nanometers, which might be possible by nanostructuring the hydrides (de Jongh and Adelhelm, 2010). For some hydrides, this strategy has been found to be successful: borohydrides (Gross et al., 2008) and alanates (Lohstroh et al., 2010) dissolved in nanoscaffolds show improved hydrogen sorption properties. Apart from shortening the diffusion path lengths, nanostructured hydrides possess a higher surface area than pure hydrides, which improves the surface reaction kinetics. There have been reports that nanostructuring can change the stability of the hydride (Lohstroh et al., 2010; Baldi et al., 2014; Griessen et al., 2016) and even its decomposition reaction path (Mueller and Ceder, 2010). Both effects might originate from an increased contribution from the surface energy relative to the volume energy (Mueller and Ceder, 2010; Fichtner, 2011; Griessen et al., 2016). It is telling that most of the research on hydrogen in nanoparticles relies on nanostructuring of palladium (Baldi et al., 2014; Griessen et al., 2016): Pd is a hydrogen absorbing, and chemically inert material, and nanostructuring recipes exist since long (Adams and Chen, 2011). The true challenge for materials science lies in finding and functionalization of non-precious metals with improved properties [e.g., as demonstrated by Lohstroh et al. (2010), see also Figure 3]. Hydrogen storage by adsorption suffers from too weak gas-solid interactions (Hirscher, 2010), much hope is laid on novel high-surface area materials with tailored (internal) surface properties such as metal-organic frameworks (Paik Suh et al., 2012).

In addition, materials science will help to improve auxiliary equipment, which makes the hydrogen technology practically possible. These are hydrogen impermeable tubes and tanks
(Schlapbach, 1992), and their counterparts: hydrogen permeable materials for membranes (Delmelle et al., 2016); and hydrogen sensors and many niche applications such as a cold-starting auxiliary for fuel cells (A Docter, 2002). Hydrogen sensors are based on changes of a specific physical property of a material induced by hydrogen, which is used as an indicator of the hydrogen concentration. Possible interactions are changes of the electronic structure-inducing electric (Wagner and Pundt, 2010) and optical changes (Gremaud et al., 2007), localized surface plasmon resonance (LSPR) sensor (Langhammer et al., 2010), adsorption of hydrogen at Schottky barriers (Sahay et al., 1991), heat from hydrogen oxidation reaction at catalytic layers (Oleksenko et al., 2014). Hydrogen-induced changes of materials properties are the origin of many characterization methods; thus materials research on sensors is linked to challenge 1 (analytics). Frontiers in Energy Research section Hydrogen Storage and Production aims at indicating such cross-relations.

\section{Challenge 3: Systems Integration}

Materials science is the response to requirements of a technology, i.e., the performance parameters are defined by the needs of the application. In emerging technologies such as the hydrogen technology, new discoveries may revolutionize the field. This may be a fruitful interrelation of science and application, but generates difficulties as well. A striking example is hydrogen storage in metal hydrides. High capacity materials such as borohydrides need operation temperatures of $300-500^{\circ} \mathrm{C}$ at pressures up to 100 bars (Lai et al., 2015). This diminishes the overall hydrogen capacity at the systems level: vessels for hydrogen at high pressure and temperature need thick walls made of special stainless steel, heat insulation and special heat exchangers (Taube, 2015). With the exception of $\mathrm{MgH}_{2}$ (see Figure 4) ${ }^{4}$, applications with

${ }^{4} \mathrm{McPhy}$ Solid Hydrogen Storage in MgH2. McPhy Energy S.A. Available at: http:// www.mcphy.com/en/products/solid-hydrogen-storage/ retrieved 2016.

${ }^{5}$ HEXIS Galileo Fuel Cell System. Switzerland: HEXIS AG Winterthur: A Company of the Viessman Group. Available at: http://www.hexis.com/en/home retrieved 2016

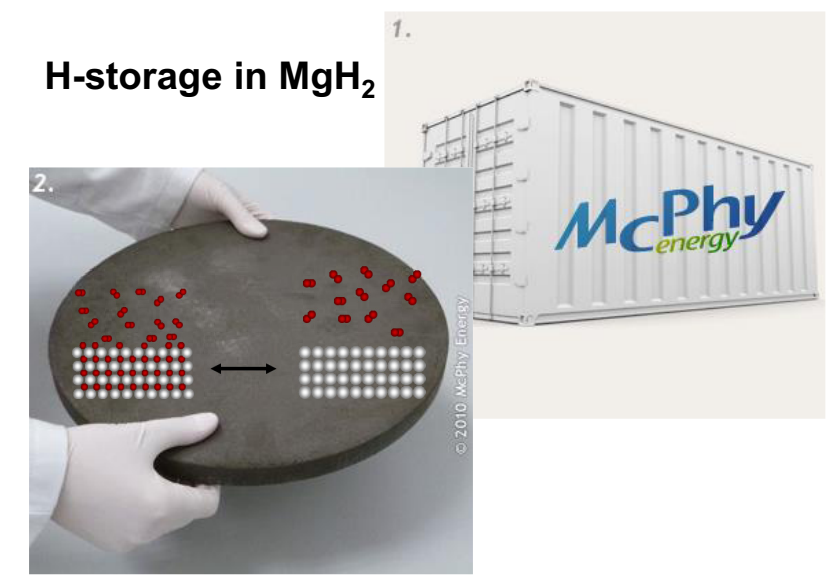

\section{SOFC for households}

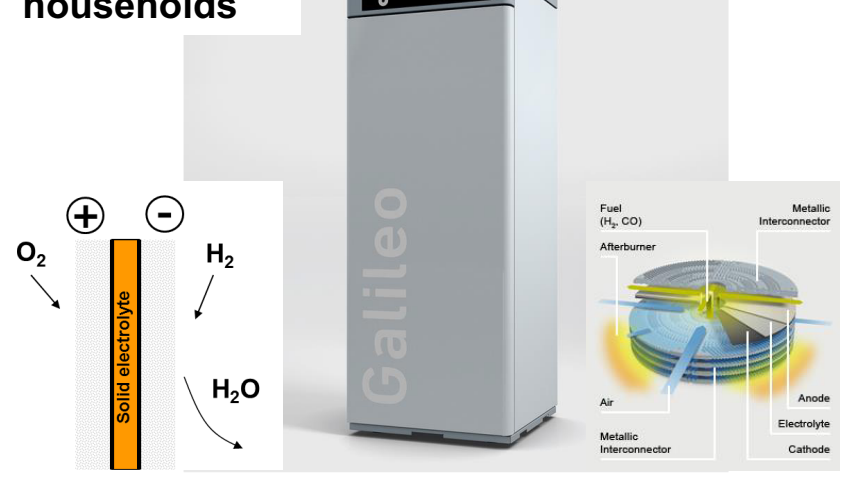

FIGURE 4 | Two examples of a successful system integration of hydrogen technology. Left side: hydrogen storage in the high-temperature hydride MgH $_{2}$ (see footnote 4). Right side: SOFC units for households to produce heat and electricity from natural gas (see footnote 5). 
high temperature hydrides are thus rare. Most solid hydrogen storage devices are still based on d-metal alloys working near room temperature and low pressures, which were developed in 70s of last century (Schlapbach, 1992; Züttel et al., 2008): hydrogen store on a canal boat (Bevan et al., 2011), hydrogen store on a resource independent living and working environment (Bielmann et al., 2011), and Ovonic Hydrogen Storage system ${ }^{6}$. Clearly, the challenge remains to push novel high capacity materials to the application level.

In general, the development of innovative ideas does not follow an engraved path. In some cases, the problem can be turned into a solution. Solid oxide fuel cells face challenges associated with the high temperatures required, i.e., heat losses as a general problem, and materials problem (leaking) due to the high operation temperature. Hexis AG offers SOFC units for households, which are meant to produce heat by default to heat households (heating/warm water) and electricity from natural gas. The open construction circumvents the leak problems, and the unreacted reactants are removed by post-combustion. The corresponding lower electric efficiency is less critical, because the heat is used for warm water (see Figure 4).

An example on the production side is the so-called biogas upgrade. Biogas is produced from biological feedstock and consists of around $60 \% \mathrm{CH}_{4}$ and $40 \% \mathrm{CO}_{2}$. The $\mathrm{CO}_{2}$ is separated from the product gas and released to the atmosphere, which is an energetically as well as economically costly process. Alternatively, the $\mathrm{CO}_{2}$ may be converted to synthetic natural gas using renewable hydrogen ["biogas upgrade" (Specht et al., 2010; Borgschulte et al., 2013, 2016)].

Pure hydrogen may be an economically attractive alternative to fossil fuel or batteries in special applications: fleets with finite daily range are refueled at their base; on-board hydrogen storage is thus of less technical importance [see, e.g., hydrogen fuel stations of COOP, Switzerland (News Release of COOP AG, 2015)].

\section{CONCLUSION}

Frontiers in Energy Research section Hydrogen Storage and Production encourages publishing such success stories to

${ }^{6}$ Ovonic Solid Hydrogen Storage Technologies. Rochester Hills, MI, USA, www.ovonic-hydrogen.com

\section{REFERENCES}

Adams, B. D., and Chen, A. (2011). The role of palladium in a hydrogen economy. Mater. Today 14, 282. doi:10.1016/S1369-7021(11)70143-2

Ambrose Evans-Pritchard. (2015). "COP-21 climate deal in Paris spells end of the fossil era," in The Telegraph. Available at: http://www.telegraph.co.uk/finance/ economics/12021394/COP-21-climate-deal-in-Paris-spells-end-of-the-fossilera.html

Baldi, A., Narayan, T. C., Leen Koh, A., and Dionne, J. A. (2014). In situ detection of hydrogen-induced phase transitions in individual palladium nanocrystals. Nat. Mater. 13, 1143. doi:10.1038/nmat4086

Bell, A. T. (2003). The impact of nanoscience on heterogeneous catalysis. Science 299, 1688. doi:10.1126/science.1083671

Bevan, A. I., Züttel, A., Book, D., and Harris, I. R. (2011). Performance of a metal hydride store on the "Ross Barlow" hydrogen powered canal boat. Faraday Discuss. 151, 353. doi:10.1039/c0fd00025f stimulate similar innovations as well as critical reviews as a starting point trigger such developments. In addition, we invite publications of critical reviews and analyses of socio-economic constraints such as:

- Materials sustainability (efficiency, abundance, toxicity, and processes);

- Business models, economic viability;

- Public acceptance, user friendliness.

With this we hope to stimulate investments in renewable hydrogen. Important international initiatives, as the EU fuel cell and hydrogen joint undertaking ${ }^{7}$, should definitely be encouraged.

The COP-21 climate deal is a great challenge to the fossil fuel industry of coal, gas, and oil, because their reserves of fossil fuels should not be burned anymore. The corresponding capital of the companies will be markedly reduced, and some economists predict significant reduction of income (Ambrose Evans-Pritchard, 2015). The author does not share this opinion because the income of the energy industry is generated by providing energy to the people. The energy demand of mankind will not decrease, i.e., the market will not diminish, and the only challenge remaining is the economically efficient production of an energy carrier - in other words the Grand Hydrogen Challenge. To satisfy the continuous increase of energy of the growing mankind will require continuous progress in energy research as well, and Frontiers in Energy Research will serve as a platform stimulating and exchanging the scientific output.

\section{AUTHOR CONTRIBUTIONS}

The author confirms being the sole contributor of this work and approved it for publication.

\section{FUNDING}

This work was partly supported by the National Research Programme "Energy Turnaround" (NRP 70) of the Swiss National Science Foundation (SNSF) Catalytic Methanation of industrially derived $\mathrm{CO}_{2}$, and the UZH-URPP program LightChEC.

${ }^{7}$ http://www.fch.europa.eu/

Bielmann, M., Vogt, U. F., Zimmermann, M., and Züttel, A. (2011). Seasonal energy storage system based on hydrogen for self sufficient living. J. Power Sources 196, 4054. doi:10.1016/j.jpowsour.2010.11.096

Borgschulte, A., Bielmann, M., Züttel, A., Barkhordarian, G., Dornheim, M., and Bormann, R. (2008). Hydrogen dissociation on oxide covered $\mathrm{MgH} 2$ by catalytically active vacancies. Appl. Surf. Sci. 254, 2377. doi:10.1016/j. apsusc.2007.09.069

Borgschulte, A., Callini, E., Stadie, N., Arroyo, Y., Rossell, M. D., Erni, R., et al. (2015). Manipulating the reaction path of the CO2 hydrogenation reaction in molecular sieves. Catal. Sci. Technol. 5, 4613. doi:10.1039/C5CY00528K

Borgschulte, A., Gallandat, N., Probst, B., Suter, R., Callini, E., Ferri, D., et al. (2013). Sorption enhanced $\mathrm{CO}_{2}$ methanation. Phys. Chem. Chem. Phys. 15, 9620. doi:10.1039/c3cp51408k

Borgschulte, A., Delmelle, R., Duarte, R. B., Heel, A., Boillat, P., and Lehmann, E. (2016). Water distribution in a sorption enhanced methanation reactor by time resolved neutron imaging. Phys. Chem. Chem. Phys. doi:10.1039/C5CP07686B 
BP Statistical Review of World Energy 2015. (2015). Available at: http://www.bp.com/ en/global/corporate/energy-economics/statistical-review-of-world-energy. html

Carmo, M., Fritz, D. L., Mergel, J., and Stolten, D. (2013). A comprehensive review on PEM water electrolysis. Int. J. Hydrogen Energy 38, 4901. doi:10.1016/j. ijhydene.2013.01.151

de Jongh, P. E., and Adelhelm, P. H. (2010). Nanosizing and nanoconfinement: new strategies towards meeting hydrogen storage goals. ChemSusChem 3, 13323. doi:10.1002/cssc.201000248

Delmelle, R., Ngene, P., Dam, B., Bleiner, D., and Borgschulte, A. (2016). Promotion of hydrogen desorption from Pd surfaces by fluoropolymer coating. Chem CatChem. doi:10.1002/cctc.201600168

Delmelle, R., Probst, B., Alberto, R., Züttel, A., Bleiner, D., and Borgschulte, A. (2015). Closing the pressure gap in $\mathrm{x}$-ray photoelectron spectroscopy by membrane hydrogenation. Rev. Sci. Instrum. 86, 053104. doi:10.1063/1.4921353

Docter, A., Frank, G., Konrad, G., Lamm, A., and Mueller, J. (2002). Fuel Cell and Method for Cold-Starting Such a Fuel Cell. US-patent US 20080102327 A1 (German patent DE10213134 A1 filed March, 2002).

Ebbesen, S. D., Jensen, S. H., Hauch, A., and Mogensen, M. B. (2014). High temperature electrolysis in alkaline cells, solid proton conducting cells, and solid oxide cells. Chem. Rev. 114, 10697. doi:10.1021/cr5000865

Erdey-Grúz, T., and Volmer, M. (1930). Zur Theorie der Wasserstoffüberspannung. Z. Phys. Chem. 150, 203.

Ertl, G. (1990). Elementary steps in heterogeneous catalysis. Angew. Chem. Int. Ed. Engl. 29, 1219. doi:10.1002/anie.199012191

ESRL Global Monitoring Division. (2015). Global Greenhouse Gas Reference Network. Boulder: NOAA.

Feldberg, S. W. (2010). Implications of Marcus-Hush theory for steady-state heterogeneous electron transfer. Anal. Chem. 82, 5176. doi:10.1021/ ac1004162

Fernández, A., Arzac, G. M., Vogt, U. F., Hosoglu, F., Borgschulte, A., Jiménez de Haro, M. C., et al. (2016). Investigation of a Pt containing washcoat on $\mathrm{SiC}$ foam for hydrogen combustion applications. Appl. Catal. B 180, 336. doi:10.1016/j. apcatb.2015.06.040

Ferri, D., Newton, M. A., and Nachtegaal, M. (2011). Modulation excitation X-ray absorption spectroscopy to probe surface species on heterogeneous catalysts. Top. Catal. 54, 1070. doi:10.1007/s11244-011-9727-5

Fichtner, M. (2011). Nanoconfinement effects in energy storage materials. Phys. Chem. Chem. Phys. 13, 21186. doi:10.1039/c1cp22547b

Frischkorn, C. (2008). Ultrafast reaction dynamics of the associative hydrogen desorption from $\mathrm{Ru}(001)$. J. Phys. Condens. Matter 20, 313002. doi:10.1088/0953-8984/20/31/313002

Gao, Y. Q., Georgievskii, Y., and Marcus, R. (2000). On the theory of electron transfer reactions at semiconductor electrode/liquid interfaces. J. Chem. Phys. 112, 3358. doi:10.1063/1.480918

Graves, C., Ebbesen, S. D., Mogensen, M., and Lackner, K. S. (2011). Sustainable hydrocarbon fuels by recycling $\mathrm{CO}_{2}$ and $\mathrm{H}_{2} \mathrm{O}$ with renewable or nuclear energy. Renew. Sustain. Energ. Rev. 15, 1. doi:10.1016/j.rser.2010.07.014

Gremaud, R., Broedersz, C. P., Borsa, D. M., Borgschulte, A., Mauron, P. H., Schreuders, H., et al. (2007). Hydrogenography: an optical combinatorial method to find new light-weight hydrogen-storage. Adv. Mater. 19, 2813-2817. doi:10.1002/adma.200602560

Griessen, R., Strohfeldt, N., and Giessen, H. (2016). Thermodynamics of the hybrid interaction of hydrogen with palladium nanoparticles. Nat. Mater. 15, 311-317. doi:10.1038/nmat4480

Gross, A. F., Vajo, J. J., Van Atta, S. L., and Olson, G. L. (2008). Nanoconfined LiBH4. J. Phys. Chem. C 112, 5651. doi:10.1021/jp711066t

Hirscher, M. (2010). "Physisorption in porous media," in Handbook of Hydrogen Storage: New Materials for Future Energy Storage (Weinheim: Wiley-VCH).

How to loose half a trillion euros. (2013). The Economist. Available at: http:// www.economist.com/news/briefing/21587782-europes-electricity-providers-face-existential-threat-how-lose-half-trillion-euros

Hsu, H.-Y., Cheng, C.-W., Huang, W.-K., Lee, Y.-P., and Diau, E. W.-G. (2014). Femtosecond infrared transient absorption dynamics of benzimidazole-based ruthenium complexes on TiO2 films for dye-sensitized solar cells. J. Phys. Chem. C 118, 16904. doi:10.1021/jp500414c

Hubbert, M. K. (1956). Nuclear Energy and the Fossil Fuels, Vol. 95. Drilling and Production Practice, American Petroleum Institute, 10237. Available at: http:// www.hubbertpeak.com/hubbert/1956/1956.pdf; http://www.peakoil.ch
Huskinson, B., Marshak, M. P., Suh, C., Er, S., Gerhardt, M. R., Galvin, C. J., et al. (2014). A metal-free organic-inorganic aqueous flow battery. Nature 505, 195. doi:10.1038/nature12909

Imbihl, R., Behm, R. J., and Schlögl, R. (2007). Bridging the pressure and material gap in heterogeneous catalysis. Phys. Chem. Chem. Phys. 9, 3459. doi:10.1039/ b706675a

Johansson, M., Lytken, O., and Chorkendorff, I. (2008). The sticking probability for $\mathrm{H} 2$ in presence of $\mathrm{CO}$ on some transition metals at a hydrogen pressure of 1 bar. Surf. Sci. 602, 1863. doi:10.1016/j.susc.2008.03.025

Kirubakaran, A., Jain, S., and Nema, R. K. (2009). A review on fuel cell technologies and power electronic interface. Renew. Sustain. Energ. Rev. 13, 2430. doi:10.1016/j.rser.2009.04.004

Kuhl, K. P., Cave, E. R., Abram, D. N., and Jaramillo, T. F. (2012). New insights into the electrochemical reduction of carbon dioxide on metallic copper surfaces. Energy Environ. Sci. 5, 7050. doi:10.1039/c2ee21234j

Lai, Q., Paskevicius, M., Sheppard, D. A., Buckley, C. E., Thornton, A. W., Hill, M. R., et al. (2015). Hydrogen storage materials for mobile and stationary applications: current state of the art. ChemSusChem 8, 2789. doi:10.1002/cssc.201500231

Langhammer, C., Larsson, E. M., Kasemo, B., and Zoric, I. (2010). Indirect nanoplasmonic sensing: ultrasensitive experimental platform for nanomaterials science and optical nano-calorimetry. Nano Lett. 10, 3529-3538. doi:10.1021/ nl101727b

Lohstroh, W., Roth, A., Hahn, H., and Fichtner, M. (2010). Thermodynamic effects in nanoscale NaAlH4. Chemphyschem 11, 789. doi:10.1002/cphc.200900767

Marcus, R. A. (1993). Electron transfer reactions in chemistry. Theory and experiment. Rev. Mod. Phys. 65, 599. doi:10.1103/RevModPhys.65.599

McFarland, E. (2014). Solar energy: setting the economic bar from the top-down. Energy Environ. Sci. 7, 846-854. doi:10.1039/c3ee43714k

Miles, M. H., Kissel, G., Lu, P. W. T., and Srinivasan, S. (1976). Effect of temperature on electrode kinetic parameters for hydrogen and oxygen evolution reactions on nickel electrodes in alkaline solution. J. Electrochem. Soc. 123, 332. doi:10.1149/1.2132820

Mitsui, T., Rose, M. K., Fomin, E., Ogletree, D. F., and Salmeron, M. (2003). Dissociative hydrogen adsorption on palladium requires aggregates of three or more vacancies. Nature 422, 705. doi:10.1038/nature01557

Mueller, T., and Ceder, G. (2010). Effect of particle size on hydrogen release from sodium alanate nanoparticles. ACS Nano 4, 5647. doi:10.1021/nn101224j

News Release of COOP AG. (2015). Coop plant die erste öffentliche WasserstoffTankstelle der Schweiz. Switzerland. Available at: http://www.coop.ch/pb/site/ medien/node/81935736/Lde/index.html; http://h2energy.ch/

Nocera, D. G. (2012). The artificial leaf. Acc. Chem. Res. 45, 767. doi:10.1021/ ar2003013

Nørskov, J. K., Rossmeisl, J., Logadottir, A., Lindqvist, L., Kitchin, J. R., Bligaard, T., et al. (2004). Origin of the overpotential for oxygen reduction at a fuel-cell cathode. J. Phys. Chem. B 108, 17886. doi:10.1021/jp047349j

O'Hayre, R., and Prinz, F. (2004). The air/platinum/nafion triple-phase boundary: characteristics, scaling, and implications for fuel cells. J. Electrochem. Soc. 151, A756. doi:10.1149/1.1701868

Oleksenko, L. P., Maksymovych, N. P., Sokovykh, E. V., Matushko, I. P., Buvailo, A. I., and Dollahon, N. (2014). Study of influence of palladium additives in nanosized tin dioxide on sensitivity of adsorption semiconductor sensors to hydrogen. Sens. Actuators B Chem. 196, 298. doi:10.1016/j.snb.2014.02.019

Paik Suh, M., Park, H. J., Prasad, T. K., and Lim, D.-W. (2012). Hydrogen storage in metal-organic frameworks. Chem. Rev. 112, 782. doi:10.1021/cr200274s

Pettinger, B., Ren, B., Picardi, G., Schuster, R., and Ertl, G. (2004). Nanoscale probing of adsorbed species by tip-enhanced Raman spectroscopy. Phys. Rev. Lett. 92, 096101. doi:10.1103/PhysRevLett.92.096101

Reier, T., Pawolek, Z., Cherevko, S., Bruns, M., Jones, T., Teschner, D., et al. (2015). Molecular insight in structure and activity of highly efficient, low-Ir Ir-Ni oxide catalysts for electrochemical water splitting (OER). J. Am. Chem. Soc. 137, 13031. doi:10.1021/jacs.5b07788

Rodenberg, A., Orazietti, M., Probst, B., Bachmann, C., Alberto, R., Baldridge, K. K., et al. (2015). Mechanism of photocatalytic hydrogen generation by a polypyridyl-based cobalt catalyst in aqueous solution. Inorg. Chem. 54, 646. doi:10.1021/ic502591a

Rupprecht, J., Hankamer, B., Mussgnug, J. H., Ananyev, G., Dismukes, C., and Kruse, O. (2006). Perspectives and advances of biological H2production in microorganisms. Appl. Microbiol. Biotechnol. 72, 442. doi:10.1007/s00253-0060528-x 
Sahay, P. P., Shamsuddin, M., and Srivastava, R. S. (1991). Effects of hydrogenation on the electrical characteristics of $\mathrm{Ni} / \mathrm{n}-\mathrm{Si}(111)$ Schottky diodes. Solid-State Electron 34, 727. doi:10.1016/0038-1101(91)90009-N

Salmeron, M., and Schlögl, R. (2008). Ambient pressure photoelectron spectroscopy: a new tool for surface science and nanotechnology. Surf. Sci. Rep. 63, 169-199. doi:10.1016/j.surfrep.2008.01.001

Schlapbach, L. (ed). (1992). "Surface properties and activation," in Hydrogen in Intermetallic Compounds II (Berlin: Springer Verlag), 15-95.

Schlapbach, L. (2009). Hydrogen-fuelled vehicles. Nature 460, 809-811. doi:10.1038/460809a

Schlaup, C., Horch, S., and Chorkendorff, I. (2015). On the stability of copper overlayers on $\mathrm{Au}(111)$ and $\mathrm{Au}(100)$ electrodes under low potential conditions and in the presence on CO and CO2. Surf. Sci. 631, 155. doi:10.1016/j.susc. 2014.06.024

Smalley, R. E. (2005). Future global energy prosperity: the terawatt challenge. $M R S$ Bull. 30, 412. doi:10.1557/mrs2005.124

Specht, M., Brellochs, J., Frick, V., Stürmer, B., Zuberbühlr, U., Sterner, M., et al. (2010). Storage of renewable energy in the natural gas grid. Erdoel Erdgas Kohle $126,342-346$.

Taube, K. (2015). EU-FP7 Project Bor4Stor (2010-2015). Available at: http:// bor4store.hzg.de/index.html.en

Tielrooij, K. J., Garcia-Araez, N., Bonn, M., and Bakker, H. J. (2010). Cooperativity in ion hydration. Science 328, 1006. doi:10.1126/science.1183512

United Nations Framework Convention on Climate Change. (2015). Paris Agreement Under the United Nations Framework Convention on Climate Change.

Voet, D., and Voet, J. G. (2011). Biochemistry, 4th Edn. Weinheim: Wiley-VCH.

Vogt, U., Borgschulte, A., and Züttel, A. (2014). Wasserstoff durch Elektrolyse. Aqua \& Gas 10:36.

Wagner, S., and Pundt, A. (2010). Electrical resistivity and hydrogen solubility of PdHc thin films. Acta Mater. 58, 1387. doi:10.1016/j.actamat.2009.10.045
Wandlowski, T. H., Ataka, K., Pronkin, S., and Diesing, D. (2004). Surface enhanced infrared spectroscopy - Au/sulphuric acid - new aspects and challenges. Electrochim. Acta 49, 1233. doi:10.1016/j.electacta.2003.06.002

Wilson, J. R., Kobsiriphat, W., Mendoza, R., Chen, H. Y., Hiller, J. M., Miller, D. J., et al. (2006). Three-dimensional reconstruction of a solid-oxide fuel-cell anode. Nat. Mater. 5, 541. doi:10.1038/nmat1668

Yang, Y., Disselkamp, R. S., Szanyi, J., Peden, C. H. F., Campbell, C. T., and Goodwin, J. G. Jr. (2006). Design and operating characteristics of a transient kinetic analysis catalysis reactor system employing in situ transmission Fourier transform infrared. Rev. Sci. Instrum. 77, 094104. doi:10.1063/1.2349602

Zhang, M., de Respinis, M., and Frei, H. (2014). Time-resolved observations of water oxidation intermediates on a cobalt oxide nano particle catalyst. Nat. Chem. 6, 362-367. doi:10.1038/nchem.1874

Züttel, A., Borgschulte, A., and Schlapbach, L. (2008). Hydrogen as a Future Energy Carrier. Heidelberg: Wiley-VCH.

Züttel, A., Remhof, A., Borgschulte, A., and Friedrichs, O. (2010). Hydrogen: the future energy carrier. Phil. Trans. R. Soc. A 368, 3329. doi:10.1098/rsta.2010. 0113

Conflict of Interest Statement: The author declares that the research was conducted in the absence of any commercial or financial relationships that could be construed as a potential conflict of interest.

Copyright (C) 2016 Borgschulte. This is an open-access article distributed under the terms of the Creative Commons Attribution License (CC BY). The use, distribution or reproduction in other forums is permitted, provided the original author(s) or licensor are credited and that the original publication in this journal is cited, in accordance with accepted academic practice. No use, distribution or reproduction is permitted which does not comply with these terms. 